\title{
Experimental Evidence of Zooplankton Control of the Species Composition and Size Distribution of Marine Phytoplankton*
}

\author{
J. H. Ryther and J. G. Sanders** \\ Woods Hole Oceanographic Institution, Woods Hole, Massachusetts 02543, USA
}

\begin{abstract}
Grazing by Acartia tonsa in large-volume $\left(1 \mathrm{~m}^{3}\right)$ enclosures caused significant changes in the abundance and species composition of natural phytoplankton. Cell densities and biomass were reduced $20-34 \%$ in two separate experiments. Calculations suggest that grazing was responsible for all of the biomass reduction that occurred. Centric diatoms, especially Skeletonema costatum, were reduced in grazed tanks relative to controls, while microflagellates were greatly increased. Accordingly, size distribution was also affected by zooplankton grazing. Grazed phytoplankton assemblages were composed of a much smaller dominant size class $(<7 \mu \mathrm{m})$ than were control assemblages $(10-15 \mu \mathrm{m})$.
\end{abstract}

\section{INTRODUCTION}

We are currently not certain of the importance of food selectivity by herbivorous zooplankton in controlling the species composition and size distribution in marine phytoplankton assemblages. Several investigators (Poulet, 1973, 1974, 1978; Wilson, 1973; Richman et al., 1977) have demonstrated the opportunistic feeding behavior of marine copepods - i. e., copepods feed on a wide range of particle sizes and are capable of shifting their selectivity to size classes of greatest relative abundance. Cowles (1979) has further demonstrated that size selectivity by marine copepods may be altered as a function of total food abundance and decreased selectivity may be expected with declining food concentrations. Parsons et al. (1969) observed reduced growth of copepod populations when only microflagellates at low food concentrations were available in the phytoplankton; however, microflagellates were grazed effectively when larger phytoplankton cells were also available. Selective feeding by zooplankton, therefore, may be an important factor controlling phytoplankton species composition and size distribution.

Some phytoplankton species may be unsuitable as

- Contribution \# 4683 from Woods Hole Oceanographic Institution

- Present address: Chesapeake Biological Laboratory, University of Maryland, P. O. Box 38, Solomons, Maryland 20688, USA

(c) by Inter-Research food for zooplankton because they are either too large, toxic, not nutritious, or not easily digestible (Droop, 1966). In addition, Provasoli (1977) suggests that seasonal variations in phytoplankton composition may affect growth rate, sexuality, and fertility of particular zooplankton. Presumably, changes in phytoplankton species composition due to anthropogenic influence would have a similar effect.

Anthropogenic stress may alter the structure of marine plankton communities in two different ways by altering either the phytoplankton or the zooplankton assemblage. These alternate pathways may lead to different patterns of size distribution within the ecosystem as a whole (Steele and Frost, 1977). Unfortunately, the pertinent pathway is not easily determined by an examination of the species present. This determination may be reached, however, by examining each assemblage separately, and as a mixture.

Our intent was to investigate alterations in phytoplankton species composition and size distribution over time due to zooplankton predation and anthropogenic stress, separately and in combination. Effects of trace metals on phytoplankton have been reported previously (Sanders et al., 1980a, b; Sanders and Vermersch, 1980). We report here the effects of zooplankton predation. Our primary goal was to document changes in species composition and size distribution of natural phytoplankton assemblages exposed to zooplankton predation relative to control assemblages containing no phytoplankton. 


\section{MATERIALS AND METHODS}

Two experiments were carried out in large-volume, continuous-flow enclosures detailed previously (Sanders et al., 1980b). In brief, the enclosures are cylindrical fiberglass tanks approximately $1 \mathrm{~m}$ diameter by $1 \mathrm{~m}$ height. When filled to experimental levels the volume is 10001 . Tanks were filled with unfiltered Vineyard Sound seawater and then operated as continuous flowthrough cultures using sand-filtered Vineyard Sound seawater without nutrient enrichment with a turnover rate of $20 \% \mathrm{~d}^{-1}$.

Obviously, changes in entrained communities will not duplicate natural events; however, our approach allows us to closely approximate natural change by using ambient temperature and natural light and nutrient regimes in relatively large experimental volumes. Control assemblages do not vary appreciably from those in Vineyard Sound; cell densities, biomass (as measured by particulate $\mathrm{C}$ and $\mathrm{N}$ concentrations and chlorophyll a), and dominant species are all similar (Sanders et al., 1980b).

In each experiment, duplicate tanks were inoculated with 100 adult Acartia tonsa; another set of duplicate tanks containing no zooplankton were used as controls. Enclosures were sampled once a week using a hand net for estimation of $A$. tonsa density. A conical (16.5 cm diameter) net of $135 \mu \mathrm{m}$ Nitex mesh on a rigid frame was pulled twice through each tank from bottom to top, sampling an area approximately $5 \%$ of the total tank volume. Sampling of enclosures just after addition of zooplankton showed that the efficiency of catch was greater than $90 \%$. We are not certain that capture efficiencies remained that high when zooplankton densities increased, but the relative efficiency of capture between tanks presumably remained constant.

Microscopic enumeration and evaluation of the phytoplankton community structure (Utermohl, 1958) and biomass estimation by particulate carbon (CHN analyzer) were performed twice weekly. Frequent analyses

Table 1. Effects of zooplankton grazing on increase $(+)$ or decrease $(-)$, relative to controls, in phytoplankton biomass, diversity, and species composition. Significant variation relative to control assemblages is noted

\begin{tabular}{|lcc|}
\hline \multicolumn{1}{c}{ Parameter } & Experiment 1 & Experiment 2 \\
\hline Density (cells $\left.\mathrm{ml}^{-1}\right)$ & $-34 \%^{\circ}$ & $-19 \%^{\circ}$ \\
Particulate carbon & $-28 \% \cdot$ & $-13 \%^{\circ}$ \\
Diversity & $-7 \%$ & $-12 \%^{\circ}$ \\
Centric diatoms & $-10 \%$ & $-13 \%^{\circ}$ \\
Pennate diatoms & $+23 \% \cdot$ & $-5 \%$ \\
Microflagellates & $+58 \% \cdot$ & $+33 \%$ \\
& & \\
Significant $(\mathrm{P}<.05)$ variation \\
\hline
\end{tabular}

(approximately every other day) of the particle size spectra were obtained using a Coulter Counter during the second experiment.

Similarity (or dissimilarity) between control and grazed phytoplankton assemblages was tested using a Student's $t$-test of the differences between paired sets (control paired with grazed) of duplicate enclosures. Assemblages were considered to be significantly different at a level of significance $P<.05$.

\section{RESULTS}

\section{Growth of Acartia tonsa}

Growth of Acartia tonsa within both experiments was rapid, with an approximate doubling time of $0.3 \mathrm{~d}^{-1}$ in the first experiment, and $0.2 \mathrm{~d}^{-1}$ in the second experiment. In the first experiment, increase in individuals was nearly linear on a log plot; however, in Experiment 2 the population experienced a one-week lag in between growth periods (Fig. 1).

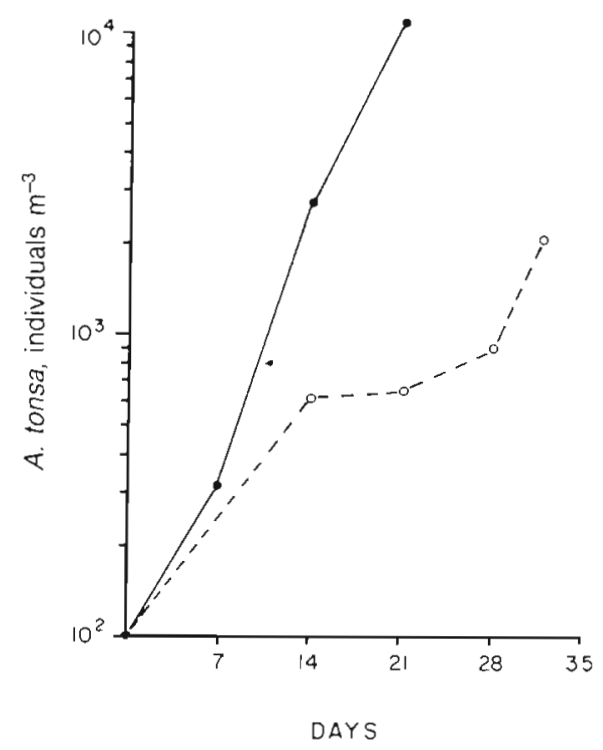

Fig. 1. Increase in Acartia tonsa copepodites and adults (individuals $\mathrm{m}^{-3}$ ) with time in large-volume enclosures in Experiments 1 (filled circles) and 2 (open circles). Zooplankton densities in control tanks were less than 50 individuals $\mathrm{m}^{-3}$ at all times

\section{Zooplankton Predation}

Grazing significantly affected phytoplankton biomass in both experiments (Table 1). Cell densities and particulate carbon were reduced by $34 \%$ and $28 \%$ in the first experiment, and by $19 \%$ and $13 \%$ in the second experiment, respectively. 
Species diversity ( $d=$ S-1/n N, Margalef, 1958) was reduced by $12 \%$ and $7 \%$ in the two experiments in the grazed tanks (Table 1); in addition, species composition within the grazed tanks differed relative to control. The predominance of centric diatoms, mainly Skeletonema costatum, was reduced by approximately $10 \%$, while microflagellates increased $60 \%$ and $35 \%$, respectively, in Experiments 1 and 2 (Table 1). Pennate diatoms increased in grazed tanks relative to control in Experiment 1, but were slightly reduced in Experiment 2.

Skeletonema costatum, the perennial dominant in our ecosystems and in Vineyard Sound, was greatly reduced by zooplankton grazing; however, this reduction was not apparent until after Day 14 in Experiment 1 and Day 11 in Experiment 2. After these dates were reached, $S$. costatum was reduced from an average of $22-34 \%$ of total cell numbers in control assemblages to only $4-7 \%$ of total in grazed assemblages.

Frequent samples were taken during Experiment 2 for Coulter Counter analysis to determine the size spectra of cells in both control and grazed assemblages. These data are graphed in Figure 2, beginning with Day 14. The dominant size class remained stable through the course of the experiment in control enclosures (A), but was greatly reduced in diameter and volume in grazed enclosures (B), indicating a reduction in mean particle size due to zooplankton grazing pressure. The number of Acartia tonsa adults and copepodites $\mathrm{m}^{-3}$ is shown in the boxes to the right of the figure. Visible changes in particle size did not become apparent until zooplankton densities reached $600-900 \mathrm{~m}^{-3}$.

\section{DISCUSSION}

Growth rates of Acartia tonsa were rapid in our enclosures. In both experiments individuals exceeded $1000 \mathrm{~m}^{-3}$; in the first experiment they exceeded $10000 \mathrm{~m}^{-3}$. The higher densities attained by A. tonsa in Experiment 1 may simply be due to higher temperatures, which ranged between 21 and $24^{\circ} \mathrm{C}$ in Experiment 1 (August), and between 12 and $19{ }^{\circ} \mathrm{C}$ in Experiment 2 (October). Heinle (1969) found that $A$. tonsa increased its generation time from a minimum of 5-7 d at $25^{\circ} \mathrm{C}$ to about $14 \mathrm{~d}$ at $15^{\circ} \mathrm{C}$, and $>3$ weeks at $10^{\circ} \mathrm{C}$. This suggests that the slower growth in Experiment 2 was not unusual. In addition to the temperature change, there was also a reduction in available food: cell densities and particulate carbon concentrations decreased by a factor of 2 from Experiment 1 to Experiment 2 . This was probably not a factor in determining growth rate of the animals, however, since $A$. tonsa never ingested more than $30 \%$ of the available carbon.

The removal of carbon within the enclosures corresponds well with published accounts of Acartia tonsa grazing rates. Assuming an average grazing rate of $9 \mu \mathrm{g} \mathrm{C}$ individual ${ }^{-1} \mathrm{~d}^{-1}$ (based on an average of rates reported by Anraku, 1964b; Hargrave and Green, 1970; Gaudy, 1974) and employing even time intervals around each zooplankton sampling date for each experiment, we find that zooplankton grazing can account for nearly all of the carbon disappearance within grazed enclosures (Table 2). Considering the probable error involved with each assumption, the agreement between carbon grazed and carbon lost is

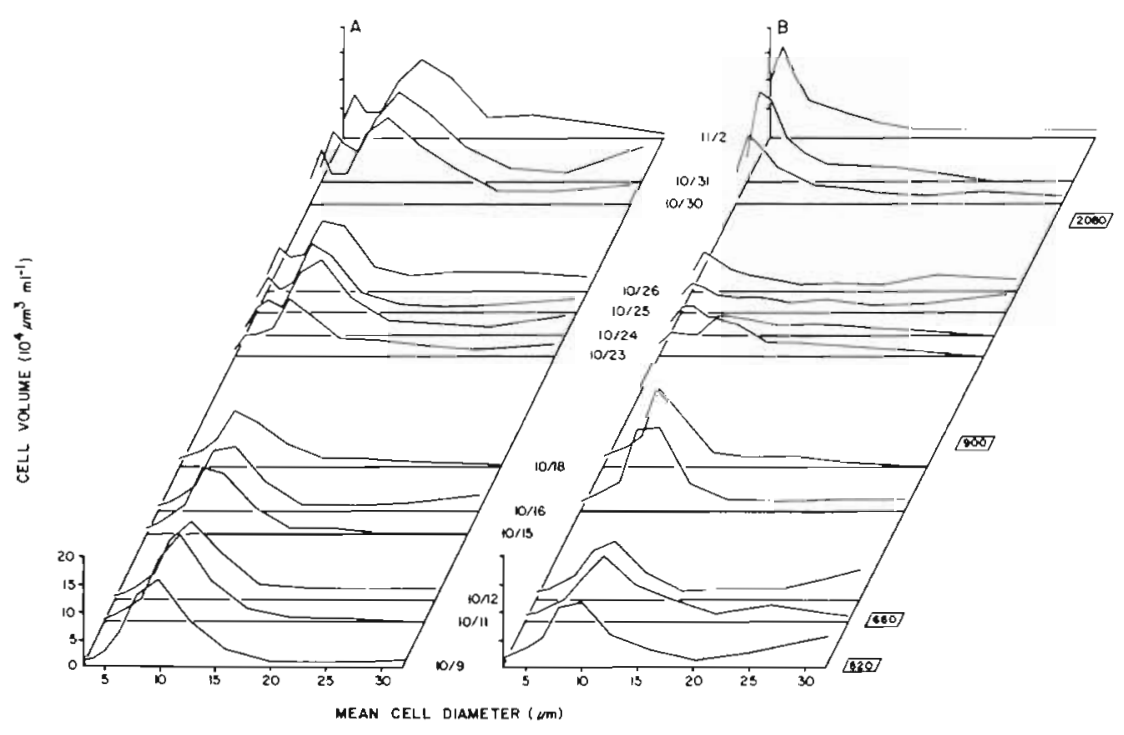

Fig. 2. Cell-size distribution with time in control (A) and grazed (B) large-volume enclosures during Experiment 2. Cell volume per size class in $10^{4} \mu \mathrm{m}^{3} \mathrm{ml}^{-1}$. First 2 weeks not shown. Zooplankton densities, in individuals $\mathrm{m}^{-3}$, in grazed tanks are displayed as framed numbers to the right of $B$ 
quite good; the difference may be due to errors involved in the calculations.

Table 2. Clearance of particulate carbon by zooplankton grazing, assuming an ingestion rate of $9 \mu \mathrm{g} \mathrm{C}$ individual ${ }^{-1} \mathrm{~d}^{-1}$ (see text) and measured zooplankton densities. Ingestion has been averaged within even time intervals placed around each sampling date. Turnover rates in each experiment were $20 \%$ $\mathrm{d}^{-1}$, thus carbon lost $\mathrm{d}^{-1}$ is assumed to be $20 \%$ of carbon reduction in grazed enclosures

\begin{tabular}{|cccccccc|}
\hline & \multicolumn{8}{c}{$\begin{array}{c}\text { Average part. C }\left(\mu \mathrm{gl}^{-5}\right) \\
\text { Grazed }\end{array}$} & $\begin{array}{c}\text { Daily } \\
\text { Closs } \\
\mathrm{mg}\end{array}$ & $\begin{array}{c}\text { Total } \\
\text { Clost } \\
\mathrm{mg}\end{array}$ & \multicolumn{2}{c|}{ C Grazed } \\
\hline 1 & 550 & 400 & 30 & 630 & 560 & 89 \\
\hline 2 & 190 & 160 & 6 & 192 & 189 & 98 \\
\hline
\end{tabular}

The effect of zooplankton grazing on phytoplankton species composition was substantial. The predominance of Skeletonema costatum and centric diatoms in general decreased significantly in the grazed assemblages, while predominance of microflagellates increased. This change is graphically most visible in the presentation of Coulter Counter data (Fig. 2). The dominant size class was initially $10 \mu \mathrm{m}$ in both sets of enclosures, but with time, dominance in the grazed enclosure shifted sharply to smaller size classes, $<7 \mu \mathrm{m}$. Again, these results are compatible with earlier investigations into the feeding behavior of Acartia tonsa which suggest that it feeds on particle sizes ranging from $7-15 \mu \mathrm{m}$ (Berman and Heinle, 1980). In this instance, the dominant size class, $10 \mu \mathrm{m}$, was largely $S$. costatum; thus it is not difficult to picture its rapid decrease in importance within the grazed assemblages. It appears that $A$. tonsa can ingest particles less than $7 \mu \mathrm{m}$, as well as larger particles, since zooplankton densities continued to increase after the shift to smaller phytoplankton occurred.

Also of note is that zooplankton densities below $600-900 \mathrm{~m}^{-3}$ did not affect size classification, although they did reduce the total particulate volume. Once above this critical density, however, large reductions in particulate volume occurred, coupled with a shift toward a much smaller dominant size class (Fig. 2). which was almost exclusively microflagellates.

The concentrations of zooplankton necessary to cause such changes are not unusually large. Carpenter et al. (1974) commonly found abundances greater than $600 \mathrm{~m}^{-3}$ from April to October in Long Island Sound. Similar densities were obtained in Buzzard's Bay and Cape Cod Canal (Massachusetts) during August and September (Anraku, 1964a).

It is interesting to note that the changes in phytoplankton species composition and size documented above are similar to those caused by higher levels of anthropogenic stress - namely, a reduction in mean size ( $\mathrm{O}^{\prime}$ Connors et al., 1978) and a reduction in dominance of centric diatoms with a concomitant increase in microflagellates and perhaps pennate diatoms (Thomas and Seibert, 1977; Sanders et al., 1980a, b). This suggests the interesting possibility that low levels of anthropogenic stress may affect phytoplankton community structure in a manner opposite to that seen with the higher levels. By selectively killing or injuring the zooplankton, low doses of stress may favor larger, centric diatoms over pennate diatoms and flagellates simply by the removal of grazing pressure, essentially as proposed by Steele and Frost (1977) and as apparently occurred in the MERL microcosms stressed with added hydrocarbons (Vargo et al., 1979). Further study of the response of zooplankton assemblages to low levels of stress is necessary in order to adequately address this possibility.

Acknowledgements. We thank for contributions to this work: J. H. Batchelder for phytoplankton enumeration, size distribution analysis, and a portion of the zooplankton enumeration; N. Corwin for particulate carbon analysis; and R. Goodlett for zooplankton sampling and enumeration. Conversations with J. H. Steele led to an examination of size distribution in the second experiment, an addition which greatly enhanced our understanding of the system. J. M. Capuzzo and $T \mathrm{~J}$. Cowles critically read the manuscript.

The project was supported by Department of Energy contract \# EY-76-S-02-2532.

\section{LITERATURE CITED}

Anraku, M. (1964a). Influence of the Cape Cod Canal on the hydrography and on the copepods in Buzzard's Bay and Cape Cod Bay, Massachusetts. I. Hydrography and distribution of copepods. Limnol. Oceanogr. 9: 46-60

Anraku, M. (1964b). Influence of the Cape Cod Canal on the hydrography and on the copepods in Buzzard's Bay and Cape Cod Bay, Massachusetts. II. Respiration and feeding. Limnol. Oceanogr 9: 195-206

Berman, M. S., Heinle, D. R. (1980). Modifications of the feeding behavior of marine copepods by sub-lethal concentrations of water-accomodated fuel oil. Mar Biol. 56: $59-64$

Carpenter, E. J., Peck, B. B., Anderson, S. J. (1974). Survival of copepods passing through a nuclear power station on Northeastern Long Island Sound, USA. Mar Biol. 24: $49-55$

Cowles, T J. (1979). The feeding response of copepods from the Peru upwelling system: food size selection. J. mar. Res. 37: 601-622

Droop, M. R. (1966). The role of algae in the nutrition of Heteramoeba clora Droop, with notes on Oxyrmis marina Dujardin and Philodina roseola Ehrenberg. In: Barnes, H. (ed.) Some contemporary studies in marine science. Allen \& Unwin, London, pp. 269-282

Gaudy, R. (1974). Feeding four species of pelagic copepods under experimental conditions. Mar. Biol. 25: 125-141

Hargrove, B. T., Green, G. H. (1970). Effects of copepod grazing on two natural phytoplankton populations. J. Fish. Res. Bd Can. 27: 1395-1403 
Heinle, D. R. (1969). Temperature and zooplankton. Chesapeake Sci. 10: 186-209

Margalef, R. (1958). Information theory in ecology. Gen. Syst. $3: 36-71$

O'Connors, H. B., Jr, Wurster, C. F., Powers, C. D., Biggs, D C., Rowland, R. G. (1978). Polychlorinated biphenyls may alter marine trophic pathways by reducing phytoplankton size and production. Science, N. Y. 201-737-739

Parsons, T R., LeBrasseur, R. J., Fulton, J. D., Kennedy, O. D. (1969). Production studies in the Straits of Georgia. II. Secondary production under the Fraser River plume, February to May, 1967. J. exp. mar. Biol. Ecol. 3: 39-50

Poulet, S. A. (1973). Grazing of Pseudocalanus minutus on naturally occurring particulate matter. Limnol. Oceanogr. 18: $564-573$

Poulet, S. A. (1974). Seasonal grazing of Pseudocalanus minutus on particles. Mar. Biol. 25: 109-123

Poulet, S. A. (1978). Comparison between five co-existing species of marine copepods feeding on naturally occurring particulate matter. Limnol. Oceanogr. 23: 1126-1143

Provasoli, L. (1977). Cultivation of animals. In: Kinne, O. (ed.) Marine ecology, Vol. III, Cultivation, Part 3. Wiley, London, pp. 1295-1319

Richman, S. Heinle, D. R., Huff, R. (1977). Grazing by adult estuarine calanoid copepods of the Chesapeake Bay. Mar Biol. 42: 69-84
Sanders, J. G., Vermersch, P. S. (1980). Response of marine phytoplankton to low levels of arsenate. (Unpublished ms)

Sanders, J. G., Batchelder, J. H., Ryther, J. H. (1980a). Dominance of a stressed marine phytoplankton assemblage by a copper-tolerant pennate diatom. Bot. Mar (in press)

Sanders, J. G., Ryther, J. H., Batchelder, J. H. (1980b). Effects of copper, chlorine, and thermal addition on the species composition of marine phytoplankton. J. exp. mar Biol Ecol. (in press)

Steele, J. H., Frost, B. W. (1977). The structure of plankton communities. Phil. Trans. R. Soc. (B) 280: 485-534

Thomas, W. H., Seibert, D. L. R. (1977). Effects of copper on the dominance and diversity of algae: controlled ecosystem pollution experiment. Bull. mar. Sci. 27: 23-33

Utermohl, H. (1958). Zur Vervollkommnung der quantitativen Phytoplanktonmethodik. Mitt. int. Verein. theor. angew. Limnol. 9: 1-38

Vargo, G., Almquist, G., Hutchins, M., Mongeon, D. (1979). Phytoplankton dynamics and production. In: Schneider, E. (project officer) The use of microcosms to determine the effects and fates of low level chronic pollutants in marine ecosystems. Report prepared for EPA under \# 806072010 pp. $84-153$

Wilson, D. S. (1973). Food size selection among copepods. Ecology 57: 909-914

This paper was presented by Dr. J. H. Ryther; it was accepted for printing on August 14, 1980 